\title{
Phylogeny of Halictidae with an emphasis on endemic African Halictinae*
}

\author{
Bryan N. DANFORTH ${ }^{1}$, Connal EARdLEY ${ }^{2}$, Laurence PACKER ${ }^{3}$, Kenneth WALKER $^{4}$, \\ Alain PAULY ${ }^{5}$, Fano José RANDRIANAMBININTSOA ${ }^{6}$ \\ ${ }^{1}$ Cornell University, Department of Entomology, 3119 Comstock Hall, Ithaca, NY 14853-0901, USA \\ ${ }^{2}$ National Collection of Insects, Biosystematics Division, Plant Protection Research Institute, Private Bag X134, \\ Pretoria 0001, South Africa \\ ${ }^{3}$ York University, Department of Biology, 4700 Keele St., Toronto, Ontario M3J 1P3 Canada \\ ${ }^{4}$ Division of Natural History, Museum of Victoria, Sciences Dept. GPO Box 666, Melbourne, 3001 Victoria, \\ Australia \\ ${ }^{5}$ Royal Belgian Institute of Natural Sciences, Department Entomology, rue Vautier 29, 1000 Bruxelles, Belgium \\ ${ }^{6}$ Département de Biologie Animale, Faculté des Sciences, Université d'Antananarivo, BP 906, Antananarivo \\ 101, Madagascar
}

Received 20 June 2007 - Revised 13 November 2007 - Accepted 15 november 2007

\begin{abstract}
We review the literature on phylogeny, fossil record, biogeography, and social evolution in Halictidae. We then present a phylogenetic analysis of tribal, generic, and subgeneric relationships within the subfamily Halictinae using a combined data set of three nuclear genes: long-wavelength (LW) opsin, wingless, and EF- $1 \alpha$. The data set includes 89 species in 34 genera representing all four halictid subfamilies, and all tribes of the subfamily Halictinae. Our study provides several new insights into the phylogeny of the African Halictinae. First, our results support a close relationship between Mexalictus (a small genus of bees occurring at high elevations in the mountains of western North and Central America) and the African/Asian genus Patellapis. Second, our results support placement of the parasitic genus Parathrincostoma well within its host genus Thrinchostoma, suggesting that Parathrincostoma should be treated as a subgenus of Thrinchostoma. Finally, our data set provides strong support for the monophyly of Patellapis (sensu Michener, 2000) and establishes monophyletic groups within the African subgenera that could be the basis for future taxonomic studies.
\end{abstract}

evolution / biogeography / bees / Apoidea

\section{INTRODUCTION}

Halictid bees are widely viewed as the "trash" bees of the world. Wheeler (1928, p. 90) commented that they "differ by such insignificant and elusive characters that they are the despair of taxonomists" and Michener (2000, p. 339) maligned them as "morpho-

Corresponding author: B.N. Danforth, bnd1@cornell.edu

* Manuscript editor: Eduardo Almeida logically monotonous". Indeed, species in some widespread subgenera (e.g., Lasioglossum [Dialictus], Halictus [Seladonia]) are difficult to identify to species and often comprise the bulk of individuals encountered when collecting bees. However, halictids encompass much more biological, behavioral, and morphological diversity than commonly perceived. Halictidae is the second largest family of bees with over 3500 described species, and many more species remain to be discovered (Packer and Taylor, 1997). They are 
distributed on all continents except Antarctica and comprise between 20 and $60 \%$ of the bee species in faunal surveys in North America, Eurasia, and South America (MacKay and Knerer, 1979; Grixti and Packer, 2006). Some halictids are oligolectic (pollen-specialists), with behavioral and morphological adaptations for collecting pollen and/or nectar from a narrow range of closely related host-plants (e.g. Systropha and Rophites in the Rophitinae, Dieunomia and Lipotriches in the Nomiinae, and Lasioglossum [Sphecodogastra] in the Halictinae). Halictidae includes numerous lineages of cleptoparastic and socially parasitic bees, and cleptoparasitism is estimated to have arisen at least eight times within Halictinae (Rozen, 2000). Halictids also show remarkable diversity in male morphologies associated with mating and courtship behavior (e.g., in Nomiinae [Wcislo and Buchmann, 1995]), but are perhaps best known for their diverse social behaviors, which include solitary, communal, semi-social and eusocial associations among adult females (see below).

Among the most interesting of the halictid bees are those from sub-saharan Africa. African halictine bees are poorly known both in terms of their phylogenetic affinities and their social behavior. In 2001 we initiated studies of the African halictine bees as part of a National Geographic project (NGS grant No. 6946-01 to BND, CE, LP, and KW). Between 2001 and 2005 we conducted field trips to South Africa (three trips), Kenya (one trip), and Madagascar (one trip) in an effort to sample and study halictid genera endemic to Africa. These studies provided important material for understanding the relationships of the African genera and for placing them in the context of a global halictid phylogeny. We report below the results of our phylogenetic analysis based on an expanded data set for these newly obtained African groups.

\subsection{Diversity in social behavior}

Halictid social behavior has been reviewed by Michener (1974, 1990), Seger (1991), Packer (1993a, 1997), Crespi (1996), Wcislo and Danforth (1997), and Schwarz et al.
(2006). Halictids are important bees for studies of social evolution because they show enormous intra- (Sakagami and Munakata, 1972; Yanega, 1988; Eickwort et al., 1996; Richards, 2000; Soucy, 2002) and inter-specific (Wcislo et al., 1993) variation in social behavior. Variation in social behavior within species is often linked with altitude and latitude such that populations at high elevation and latitude tend to be solitary, while populations at lower elevation and latitude tend to be eusocial (Sakagami and Munakata, 1972; Packer et al., 1989; Eickwort et al., 1996; Soucy, 2002; Soucy and Danforth, 2002). Diversity in social behavior among species was often thought to be due to frequent independent origins of eusociality in halictids (Eickwort, 1986) but recent molecular studies within and among genera of Halictinae have suggested that reversals from eusociality to solitary nesting may be common (Packer, 1997; Danforth, 1999; Danforth et al., 1999, 2003; Brady et al., 2006). Based on these studies, eusociality is estimated to have arisen just three to four times within Halictidae (Danforth, 1999; Brady et al., 2006; Coelho, 2002). Dating analyses based on relaxed clock methods (Brady et al., 2006) indicate that eusociality evolved recently in halictid bees (2022 myBP). The impressive intraspecific variation in sociality within halictid species, their tendency to revert from eusociality to solitary nesting, and the recency of eusocial origins are all consistent with the view that halictids are in an early stage of social evolution relative to more advanced social taxa such as corbiculate bees, vespid wasps and ants (Brady et al., 2006).

\subsection{Fossil record and antiquity}

The halictid fossil record was reviewed by Engel (2001) as part of a complete review of Baltic amber bees. Halictid bees are present in the Baltic (Engel, 2001) and Dominican amber deposits (Engel, 1995, 1996, 2000; Engel and Rightmyer, 2000). All known halictid fossils are members of the tribes Augochlorini (Engel, 1995, 1996, 2000; Engel and Rightmyer, 2000), Halictini (Engel, 2001), and Caenohalictini (Michener and Poinar, 1996). 


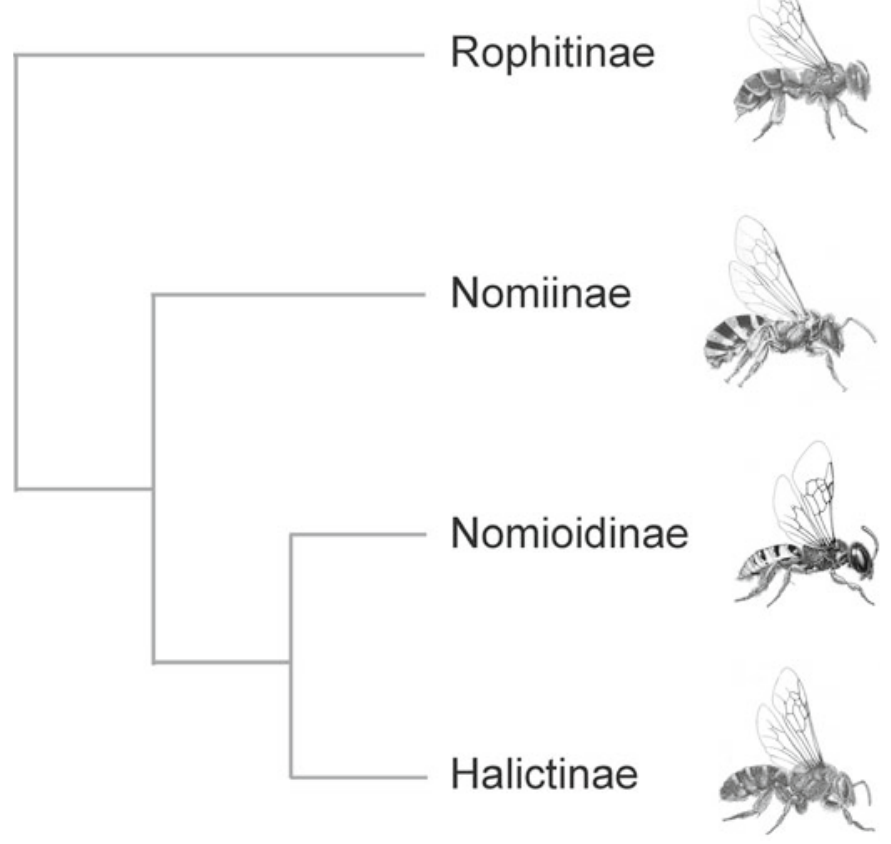

Figure 1. Subfamily-level phylogeny for the Halictidae based on morphology (Pesenko, 1999) and DNA sequence data (Danforth et al., 2004). Habitus drawings are as follows: Rophitinae (Rophites algirus), Nomiinae (Lipotriches [Austronomia] australica), Nomioidinae (Nomioides facilis), Halictinae (Agapostemon angelicus). All drawings were done by Frances Fawcett except the Lipotriches, which is reproduced with permission from Insects of Australia, 2nd edition, Vol. II, p. 997, Fig. 42.45 (permission to use figures granted by CSIRO Australia and Cornell University Press).

Given the presumed phylogenetic affinities of these tribes (see below), this suggests that much of halictid evolution occurred prior to the oldest fossil (Electrolictus antiquus; Engel, 2001), which is estimated to be 42 million years old. Estimates based on fossil-calibrated chronograms (Danforth et al., 2004) suggest that all four subfamilies diverged well before the Cretaceous/Tertiary $(\mathrm{K} / \mathrm{T})$ boundary (65 my BP). A compression fossil from the Early Eocene (52-54.5 myBP) Quilchena site in British Columbia (Engel and Archibald, 2003) is seemingly a halictine, but assignment to tribe or genus is problematic. Nel and Petrulevièius (2003) recently described a $L a$ sioglossum from Oligocene deposits in France. Despite the extensive fossil record of halictid bees (as compared to most other bee families), the minimum age estimate obtained from the fossils alone is considerably inferior to estimates based on combining molecular and fossil data (Danforth et al., 2004; Brady et al., 2006).

\subsection{Previous phylogenetic studies}

Recent phylogenetic results based on a combination of molecular and morphological data support the sister-group relationship between Halictidae and Colletidae + Stenotritidae (Danforth et al., 2006). Both morphological (Pesenko, 1999) and molecular (Danforth et al., 2004) studies support the monophyly of the four traditionally recognized subfamilies: Rophitinae, Nomiinae, Nomioidinae, and Halictinae. Relationships among the four subfamilies are reasonably well supported (Fig. 1). Rophitinae comprises genera that are unique among halictid bees in that virtually all species are host-plant specialists (Patiny et al., 2007). Preferred host plants are restricted to the 
Euasterid I clade, and the orders Gentianales, Lamiales, and Solanales appear to be the most important host plants. Patiny et al. (2007) provide a generic-level phylogeny for the subfamily based on a combination of morphological and molecular data and divided the subfamily into four monophyletic tribes (Penapini, Conanthalictini, Xeralictini and Rophitini; Fig. 2). Their tree implies frequent hostshifting in the Rophitinae with little evidence of co-cladogenesis between bees and their host plants (Patiny et al., 2007).

Nomiinae is a primarily paleotropical group with a diversity of genera in the African and Asian tropics and a small number of genera in Europe and North America. They are absent from South America and only enter the Neotropics in Cuba and southern Mexico. Nomiinae includes the only ground-nesting, solitary bee ever managed for commercial pollination: Nomia melanderi (Bohart, 1972). Catalogs exist for the African (Pauly, 1990), Australian (Cardale, 1993; Walker, 2006), and Western Hemisphere faunas (Moure and Hurd, 1987), but no detailed phylogenetic studies have been conducted at the generic, subgeneric, or species levels. This is unfortunate because the Nomiinae are a biologically fascinating group with bizarre and elaborate male morphologies (mostly involving hind legs [see Ribble, 1965 for illustrations] and genitalia) and courtship behaviors involving acoustic communication (Wcislo et al., 1992; Wcislo and Buchmann, 1995). Social behavior varies from species that nest solitarily to communal associations (Batra, 1966b; Wcislo, 1993; Vogel and Kukuk, 1994; Wcislo and Engel, 1997). Some species are host-plant specialists (Minckley et al., 1994) while others are clearly polylectic (Wcislo, 1993). In southern Africa, many species in the genus Lipotriches (subgenus Lipotriches) are narrowly oligolectic grass specialists that fly early in the morning before wind disperses the grass pollen (Immelman and Eardley, 2000; Tchuenguem Fohouo et al., 2002, 2004). Phylogenetic studies would help define more accurately the genera within Nomiinae, some of which are questionably monophyletic (e.g., Nomia, Lipotriches).

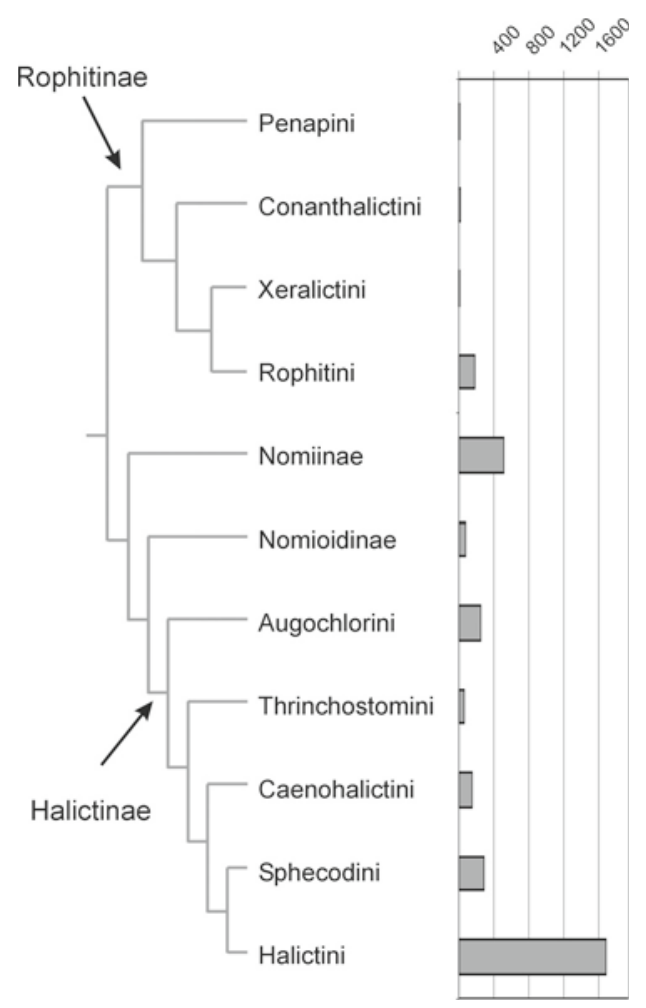

Figure 2. Relationships among subfamilies and tribes based on previous studies (Danforth et al., 2004; Patiny et al., 2007). Histogram at right shows the number of described species (data from Michener, 2000).

Nomioidinae are sometimes treated as a tribe of Halictinae (Engel, 2005), but they are morphologically very distinct and subfamily status seems warranted (Pesenko, 1999; Pesenko and Pauly, 2005). Nomioidinae include small to tiny metallic blue-green and yellow bees which occur primarily in arid regions of southern Europe, Africa and Madagascar, central Asia, and Australia (a single species, Ceylalictus (Ceylalictus) perditellus, occurs in Australia). Pesenko (2000) provided a phylogeny for Nomiodinae based on morphology and hypothesized an African origin, and Pesenko and Pauly (2005) revised the subfamily in Africa (excluding Madagascar). A diverse fauna exists in arid regions of Madagascar (Pauly et al., 2001). Some species of Nomioidinae are reported to be solitary (Radchenko, 1979) while others are reported 
to form communal associations among nestmates (Batra, 1966a).

Halictinae is the largest subfamily of halictid bees and it includes over 2400 species (Michener, 2000) in five tribes (Danforth et al., 2004) (Fig. 2). Foundations for halictine classification were laid by Michener (1978a,b) in his studies of the "strong-veined" genera. Halictinae is an enormous group and includes all of the eusocial and cleptoparasitic lineages of Halictidae. The group is clearly monophyletic with several morphological synapomorphies (including the divided prepygidial fimbria on the female T5). Tribes recognized by Danforth et al. (2004) include Augochlorini, Thrinchostomini, Caenohalictini, Sphecodini, and Halictini sensu sticto. Recognition of five tribes rather than the traditional two (Augochlorini and Halictini sensu lato; e.g., Michener, 2000) highlights the strikingly different morphologies and behaviors of these groups. The classification presented by Engel $(2005 ;$ p. 28) is not based on a phylogenetic analysis of the group and recognizes paraphyletic taxa ("Tribe Halictini" and "Subtribe Halictina" sensu Engel).

Much phylogenetic work has been done in the Augochlorini (Eickwort, 1969b; Danforth and Eickwort, 1997; Engel, 2000). Recent morphological studies (Engel, 2000) have supported monophyly of two major lineages: the subtribe Corynurina (including Corynura, Halictillus and Rhinocorynura) and the subtribe Augochlorina (the remaining genera). However, relationships at the generic and subgeneric levels were not robustly supported based on morphology alone. Augochlorini is a primarily Neotropical group with some representatives in temperate parts of North and South America. Social behavior is highly variable among species and genera and recent reports of facultative eusociality in $\mathrm{Au}$ gochloropsis (Coelho, 2002) and Megalopta (Arneson and Wcislo, 2003; Smith et al., 2003; Wcislo et al., 2004) suggest that we are far from having a clear understanding of the full range and taxonomic distribution of eusociality. There are three cleptoparasitic genera/subgenera (Temnosoma, Megalopta [Noctoraptor], and Megommation [Cleptommation]) which appear to represent recent and independent derivations of cleptoparasitism.
Thrinchostomini currently includes two closely related genera (Thrinchostoma and Parathrincostoma) of large, non-metallic bees. Thrinchostomini are restricted to the African and Asian tropics and Madagascar (Pauly et al., 2001). Of the 56 species of Thrinchostoma, 12 are endemic to Madagascar (Pauly et al., 2001). Some species are host-plant specific, with Asian species of Diagonozus apparently specializing on elongate flowers of the genus Impatiens (Sakagami, 1991; Sakagami et al., 1991). In Madagascar Thrinchostoma are collected on Melastomataceae, Malvaceae, Mimosaceae, Verbenaceae, Acanthaceae, and Asteraceae (Pauly et al., 2001). Melastomataceae has poricidal anthers and female Thrinchostoma "buzz" the flowers when foraging (Pauly et al., 2001). We have also observed this behavior on Solanum in South Africa and on Melastomataceae in Madagascar (BND, pers. obs.). We know little about the nesting biology or social behavior of Thrinchostomini, although their phenology in southern Africa would suggest that they are solitary. Parathrincostoma includes two species that are endemic to Madagascar. Females lack pollen collecting structures and are inferred to be cleptoparasites of Thrinchostoma (Michener, 1978a, 2000), although this has never been verified through nest excavations.

Caenohalictini (like Augochlorini) is restricted to the New World and includes the large, mostly metallic bees related to Agapostemon. Eickwort (1969a) described the numerous morphological characters that distinguish this group from the superficially similar Augochlorini and Roberts and Brooks (1987) provided a generic-level revision of the tribe. Janjic and Packer (2003) analyzed the phylogeny of Agapostemon based on morphology using three other genera as outgroups. Unlike Augochlorini, which includes eusocial species, species of Caenohalictini are either solitary or communal (Abrams and Eickwort, 1980; Packer, 2006). Some genera (e.g., Rhinetula) are nocturnal bees with enlarged ocelli and compound eyes. Females of many species in other genera appear to be particularly active in the early morning.

Sphecodini includes four genera of cleptoparasitic bees (Michener, 1978a). Females 
in these genera enter the nests of other bees and lay their eggs on or near the host's pollen provisions. Like other cleptoparasitic bees, females lack pollen-collecting structures and are heavily sclerotized. Sphecodes is the largest genus and is widespread on all continents except Australia. Hosts of Sphecodes include solitary and social Halictinae, Nomioidinae (Nomioides), Andrenidae (Andrena, Calliopsis, Melitturga, and Perdita) and Colletidae (Colletes and Lonchopria) (Michener, 2000). Unlike many cleptoparasitic bees, female Sphecodes aggressively attack the host female (or females in social nests) and may kill the host female(s) before oviposition in recently provisioned cells (Legewie, 1925; Knerer, 1973; Danforth, 1989; Sick et al., 1994). Female Sphecodes monilicornis were observed to close the host (Lasioglossum malachurum) cells following oviposition and a single female can lay multiple eggs per nest (Sick et al., 1994). Detailed studies on the mode of parasitism in Sphecodes are needed. Bogusch et al. (2006) recently documented interesting patterns of intra-specific host specialization in two species of Sphecodes (S. ephippius and S. monilicornis). While the species are generalists in the sense that members attack diverse host species, individuals appear to specialize on particular host species. Rigorous phylogenetic studies have not been conducted for this group. Because they are cleptoparastic they tend to be rare and associating males and females has been difficult in some cases.

Halictini is the largest tribe of halictid bees and includes over 1600 described species (Fig. 2). A single genus (Lasioglossum sensu lato) accounts for over $70 \%$ of the species (Michener, 2000). Lasioglossum includes solitary, communal, eusocial, and socially parasitic species. Lasioglossum is particularly diverse in Australia where over 350 species occur (Cardale, 1993; Walker, 1986, 1995, 1997; Michener, 2000). Several species of Australian Lasioglossum are communal and some species are known in which males are dimorphic, with large-headed flightless males that remain within the nest and small-headed flight-capable males that can be collected on flowers (Knerer and Schwarz, 1976, 1978;
Kukuk and Schwarz, 1987, 1988; Kukuk and Crozier, 1990; Kukuk, 1992; Kukuk and Sage, 1994; McConnel-Garner and Kukuk, 1997). Some Lasioglossum are crepuscular and/or matinal fully nocturnal (e.g., Sphecodogastra) and narrow host-plant preferences are known in some Lasioglossum subgenera (e.g., Sphecodogastra on Onagraceae and Hemihalictus on Pyropappus [Asteraceae]). Lasioglossum in our sense includes groups traditionally treated as genera (e.g., Homalictus, Echthralictus, and Urohalictus). Echthralictus is a cleptoparasitic lineage closely related to, and presumably derived from, Homalictus (Michener, 2000). Our previous molecular data sets (Danforth and Ji, 2001; Danforth et al., 2004) have placed Homalictus (and presumably also Echthralictus) well within the larger genus Lasioglossum. Examination of the type species of Urohalictus indicates that it is similar to L. (Parasphecodes) and most likely a distinct subgenus of Lasioglossum (Danforth, pers. obs.). Homalictus, Echthralictus and Urohalictus all share the weakened outer wing venation that unites Lasioglossum and we believe the phylogenetic evidence would support treating these groups as subgenera of Lasioglossum. Mexalictus is an enigmatic genus of strong-veined halictine bees that occurs at high elevations from southeastern Arizona to northern Guatemala. These are rare bees that are collected in humid forests at elevations between $\sim 2000$ and $\sim 3000 \mathrm{~m}$ (Eickwort, 1978; Packer, 1993b). Nothing is known of their social behavior or floral associations, although they appear to be solitary and polylectic. There are six described species. Most species are weakly metallic and resemble large, slender Lasioglossum (subgenus Dialictus). However, they lack the weakened outer wing veins of Lasioglossum and clearly represent a distinct strong-veined lineage (Eickwort, 1978). Among the most interesting halictine bees are those treated by Michener (2000) as the genus Patellapis. The genus is most diverse in southern Africa (with many subgenera including Patellapis sensu stricto, Zonalictus, Chaetalictus, Lomatalictus, and Dictyohalictus) and Madagascar (with endemic subgenera, such as Madagalictus and Archihalictus). One subgenus (Pachyhalictus) 
Table I. Alternative classifications of "Patellapis" sensu lato.

\begin{tabular}{|c|c|}
\hline Pauly 1999 & Michener 2000 \\
\hline Genus Patellapis Friese & Genus Patellapis \\
\hline Subgenus Patellapis Friese• & Subgenus Archihalictus $^{1} \bullet$ \\
\hline Subgenus Lomatalictus Michener• & Subgenus Chaetalicus $\bullet$ \\
\hline \multirow[t]{2}{*}{ Subgenus Chaetalictus Michener• } & Subgenus Dictyohalictus \\
\hline & Subgenus Lomatalictus• \\
\hline \multirow{2}{*}{ Genus Madagalictus Pauly? } & Subgenus Pachyhalictus $\bullet$ \\
\hline & Subgenus Patellapis• \\
\hline Genus Pachyhalictus Cockerell & Subgenus Zonalictus• \\
\hline Subgenus Pachyhalictus Cockerell• & \\
\hline Subgenus Dictyohalictus Michener & \\
\hline Subgenus Archihalictus Pauly• & \\
\hline
\end{tabular}

${ }^{1}$ including Madagalictus Pauly.

- Subgenera sampled in our study.

occurs in tropical Asia (Pauly, 2007) and northern Australia (Walker, 1993, 1996). Little is known about the social behavior in the over 160 species of Patellapis s.l.. Timmermann and Kuhlmann (2008) recently provided the first detailed observations of nesting, foraging, and social behavior in this genus and found that female are polylectic foragers and that they form communal nests with up to eight females. Little is known about the phylogenetic affinities of Patellapis and the monophyly of the genus is not well supported by morphology. Conflicting classifications exist for this group (Tab. I). Pauly $(1999,2007)$ recognized three genera whereas Michener (2000) recognized a single, large genus (Patellapis) with multiple subgenera. It is worth noting that the oldest fossil halictid bee, Electrolictus antiquus from the Baltic amber (Engel, 2001), would be placed in the tribe Halictini sensu stricto and, in fact, may be very close to a Patellapis.

Previous phylogenetic studies of Halictinae (e.g., Danforth et al., 2004) were based on limited sampling of the African genera (including Patellapis [and its many subgenera], Thrinchostoma, Parathrincostoma, and Nomioidini). In 2001 we initiated several collecting trips to Africa and Madagascar to obtain and study a representative sample of African halictine bees. As a result of these trips we have been able to include all the major African genera and subgenera in an expanded data set. We report below the analysis of this data set based on parsimony. Our results establish more clearly the affinities of the African halictine bees.

\section{MATERIALS AND METHODS}

\subsection{Data sets}

We generated a data set based on three single copy nuclear genes: wingless, LW rhodopsin and elongation factor- $1 \alpha$. Primers and sequencing protocols were provided in Danforth et al. (2004) and follow standard methods detailed in Danforth (1999), Ascher et al. (2001), and Danforth and Ji (2001). For more detailed information on genes and primers see http://www.entomology.cornell.edu/BeePhylogeny/

We added 31 species to the original data set (Danforth et al., 2004), including several additional genera and species of Nomioidinae, Thrinchostomini, Halictini and Sphecodini (see supplementary Table published as online material). Most new species were collected in South Africa and Madagascar. Species identifications were made by BND, $\mathrm{KW}, \mathrm{CE}$ and LP. The total data set consisted of 89 species in 34 genera representing all four halictid subfamilies, and all tribes of the subfamily Halictinae (see supplementary Table published as online material). Numerous subgenera were included for the larger genera, such as Halictus, Lasioglossum, and Patellapis. For Patellapis we included all genera/subgenera recognized by Michener (2000) and Pauly $(1999,2007)$ (Tab. I) excluding Patellapis 
Table II. Descriptive results for each gene and nucleotide position.

\begin{tabular}{ccccc}
\hline & $\begin{array}{c}\text { No. } \\
\text { Sites }\end{array}$ & $\begin{array}{c}\text { No. PI } \% \\
\text { sites }\end{array}$ & A/T & $P$ \\
\hline Opsin & & 65 & 57.15 & $1.00(\mathrm{~ns})$ \\
nt1 & 234 & 32 & 56.61 & $1.00(\mathrm{~ns})$ \\
nt2 & 234 & 182 & 31.71 & $0.219(\mathrm{~ns})$ \\
nt3 & 234 & & & \\
Wingless & & 24 & 41.72 & $1.00(\mathrm{~ns})$ \\
nt1 & 137 & 4 & 54.27 & $1.00(\mathrm{~ns})$ \\
nt2 & 137 & 113 & $\mathbf{1 4 . 7 8}$ & $<0.001$ \\
nt3 & 137 & & & \\
EF-1 $\alpha$ & & 37 & 44.27 & $1.00(\mathrm{~ns})$ \\
nt1 & & 58.21 & $1.00(\mathrm{~ns})$ \\
nt2 & 376 & 302 & $\mathbf{5 5 . 6 1}$ & $<0.001$ \\
nt3 & 376 & 19 & 61.08 & $1.00(\mathrm{~ns})$ \\
intron & 375 & & & $0.478(\mathrm{~ns})$ \\
overall & 296 & 952 & 49.97 & \\
\hline
\end{tabular}

${ }^{1} P$-value corresponds to the probability of rejecting the null hypothesis of homogeneity among taxa in base composition. Values in bold indicate significant deviation in base composition. "ns" indicates non-significant deviations from the null hypothesis of equal base frequencies across all taxa.

(Dictyohalictus), a subgenus of 12 rarely-collected species distributed through western (Gabon, Ivory Coast, Congo), eastern (Kenya, Uganda), and southern (Zimbabwe, South Africa) Africa (Pauly, 2007). We included all three subgenera of Thrinchostoma as well as their cleptoparasite (Parathrincostoma). Supplementary table (published as supplementary online material) shows the complete list of taxa, locality data, and Genbank accession numbers. Genbank accession numbers for the newly added taxa are EU203218-EU203307. Voucher specimens are deposited in the Cornell University Insect Collection. Our combined data set is available on supplementary online material.

\subsection{Phylogenetic methods}

Alignments for all genes were generated in the Lasergene DNA Star software package using Clustal W. Reading frames and intron/exon boundaries were determined by comparison with published coding sequences for the honey bee, Apis mellifera (opsin [U26026], EF-1 $\alpha$ [AF015267]) and for Drosophila (wingless [J03650]).

We performed parsimony analyses using Paup* v. $4.0 \mathrm{~b} 10$ (Swofford, 2002). Initially we performed equal weights parsimony analyses on each of the three data sets and then combined the data sets into a single analysis. We saw no obvious incongruence among data sets. Branch support for the individual data sets as well as the combined data set was estimated using bootstrap analysis (Felsenstein, 1985). For parsimony searches we performed 1000 random sequence additions. For calculating bootstrap proportions we performed 500 replicates with 10 random sequence additions per replicate.

\section{RESULTS}

The combined three-gene data set consisted of a total of 2539 aligned nucleotide sites (Tab. II). We excluded introns within opsin because they did not appear to be alignable. Conserved intron regions within $\mathrm{EF}-1 \alpha$ were included ("introns included" below) or excluded ("introns excluded" below). With introns included we obtained 952 parsimony informative sites. With introns excluded we obtained 778 parsimony informative sites. While the overall data set showed an unbiased base composition, some partitions of the data set showed substantial base compositional bias (Tab. II). Wingless third positions are $\mathrm{G} / \mathrm{C}$ rich, while $\mathrm{EF}-1 \alpha$ third positions are $\mathrm{A} / \mathrm{T}$ rich. For all three genes combined there was no 
significant base compositional heterogeneity among taxa (Tab. II). The data set is complete for all genes and for all taxa except for four missing EF-1 $\alpha$ sequences, one missing wingless sequence, and two missing opsin sequences (supplementary Table published as online material). This represents $3.2 \%$ of the total aligned data set in terms of base pairs.

Analysis of the three gene data set with and without conserved regions of the EF- $1 \alpha$ introns provided largely congruent results. Analyses with introns included resulted in 24 trees of 5839 steps. Analysis with introns excluded resulted in 60 trees of 4692 steps. Figure 3 shows the consensus tree based on the analysis with introns included. Bootstrap values above the nodes are those calculated with introns included; bootstrap values below the nodes are calculated with introns excluded. Our trees recover each of the subfamilies and tribes described above with a high level of support (bootstrap values $>95$ when introns are included). The branching pattern of the halictid tribes corroborates an earlier study (Danforth et al., 2004), but some nodes are weakly supported (Fig. 3). Relationships within Halictini support monophyly of Patellapis in the sense of Michener (2000). Interestingly, our results place Patellapis as sister to Mexalictus, a small genus of poorly known species endemic to high altitude regions of the southwestern US, northern Mexico and Central America. While this node is not strongly supported (bootstrap value of 60 with introns included) there are morphological similarities between Patellapis and Mexalictus (Michener, 2000). If correct, this result would suggest that Mexalictus represents a highly relictual genus widely separated from its closely related Asian/African sister group (Patellapis).

Relationships within the African taxa suggest that some genera may be paraphyletic. Parathrincostoma, for example, arises within Thrinchostoma. Relationships within Patellapis suggest that some currently defined subgenera (Zonalictus, Patellapis, Chaetalictus) may be paraphyletic and in need of revision. Our topology suggests that the generic/subgeneric classification proposed by Michener (2000; Tab. I) more accurately reflects the topological relationships among the subgenera than that of Pauly (1999, 2007). Pauly's genus Pachyhalictus (including Pachyhalictus sensu stricto, Dictyohalictus and Archihalictus) appears to be paraphyletic based on our analysis. Patellapis (sensu Pauly, 1999, 2007) is also apparently paraphyletic. Interestingly, the sole representative of the Asian Patellapis (Pachyhalictus sp.) is nested within a group of Madagascan species (Fig. 3). Finally, our results place Eupetersia within Sphecodes, supporting monophyly of Sphecodini, but paraphyly of Sphecodes. Figure 4 summarizes the relationships obtained based on this study. There remains some uncertainty about the tribal relationships, as well as the relationships among the three major branches of Halictini. An earlier study (Danforth et al., 2004) supported a grouping of Lasioglossum as sister to Halictus + Thrincohalictus. The current data set supports placement of Halictus + Thrincohalictus as sister to Patellapis.

\section{DISCUSSION}

Overall, our results provide the first analysis of halictine genera with the inclusion of all the major African taxa. Our study provides a basis for future taxonomic revisionary work on the genera of African halictine bees. Table III presents a revised classification based on these results.

Placement of Mexalictus as sister to the African/Asian genus Patellapis, while weakly supported, suggests a remarkable biogeographic disjunction between mountainous regions of western North America and southern Africa. Michener (2000, p. 340) noted the morphological similarity between the two genera and stated that Mexalictus and Patellapis sensu stricto "could both be archaic types surviving in limited areas." It seems likely that ancestral forms of this group were widely distributed throughout the northern Hemisphere and southward into Africa at some point in the past because dispersal from Africa to southwestern North America (or vice versa) seems an unlikely scenario. The relictual distribution of Mexalictus (restricted to humid forests at 2000-3000 m elevation) would likely have arisen as western North America became more arid during the Pleistocene. 


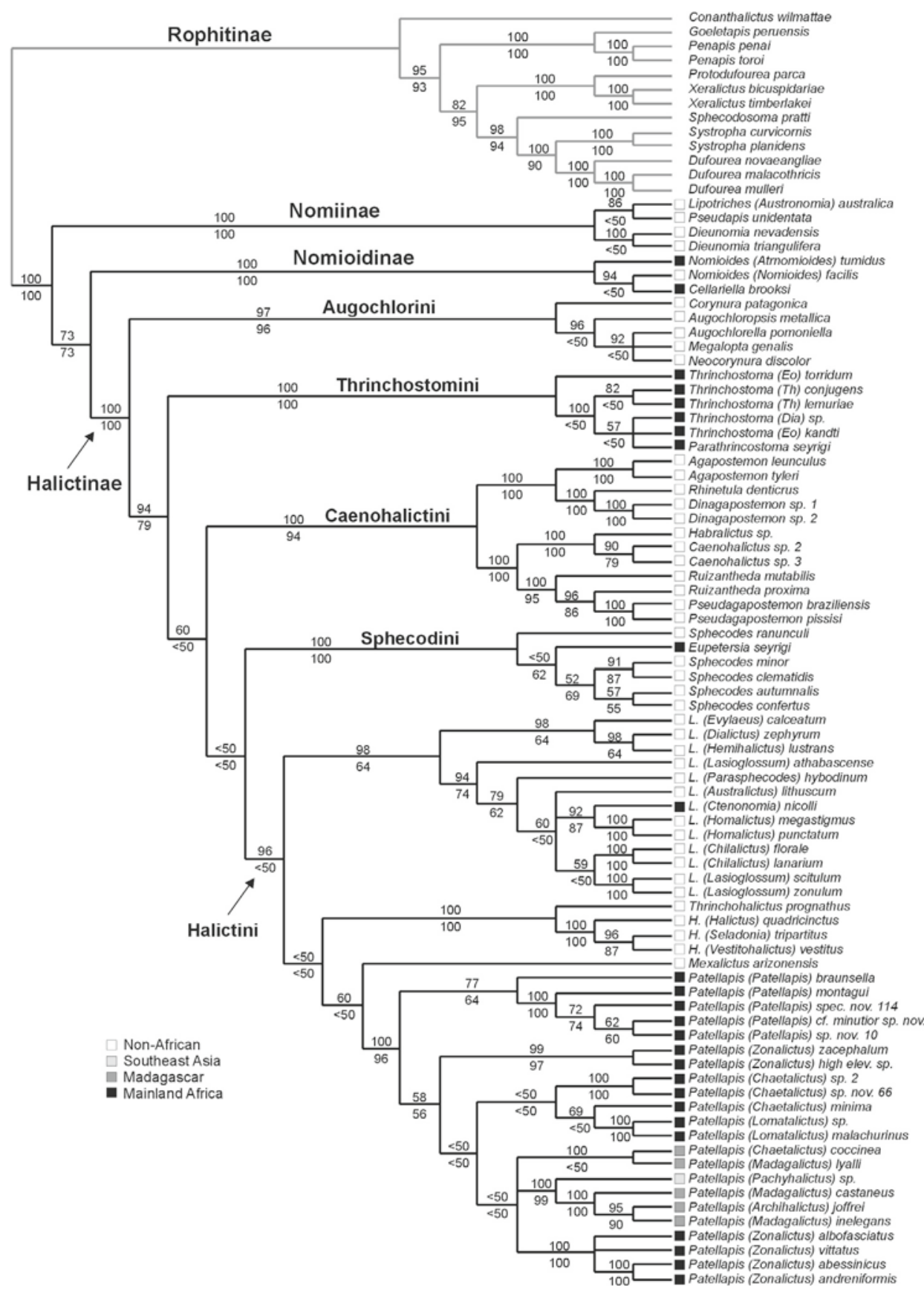

Figure 3. Parsimony analysis of the three-gene data set. Bootstrap values are shown above the nodes for the exon+intron analysis; values below the nodes for the analysis of exons alone. Shaded boxes indicate the geographic location of the taxa sampled. Open boxes indicate non-African taxa; shaded boxes indicate taxa from Madagascar; lightly shaded boxes indicate taxa from southeast Asia; black boxes indicate mainland African taxa. 


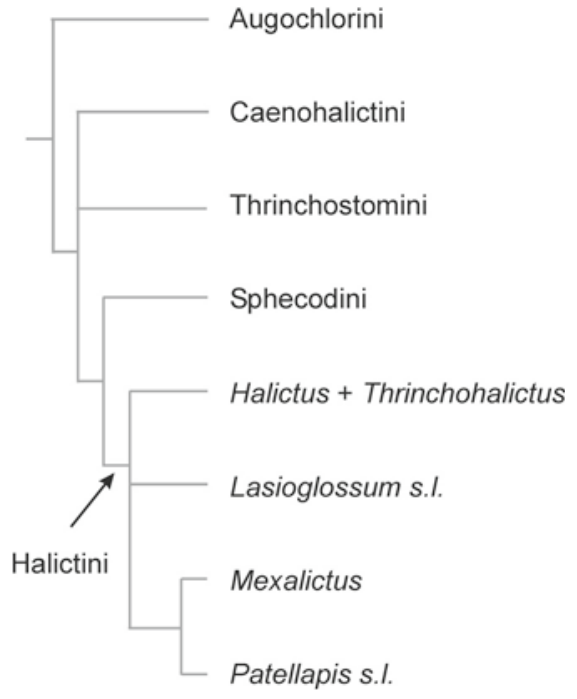

Figure 4. Summary cladogram showing relationships among tribes and select genera of Halictinae. Nodes that were not well supported (based on bootstrap analysis) are collapsed.

Mexalictus arizonensis would have to be considered a bee of conservation concern in the United States because of its limited distribution near the tops of a few mountains in southern Arizona. In terms of "phylodiversity" (Faith, 1992), Mexalictus represents an extremely important lineage in North and Central America.

Another important finding is the placement of Parathrincostoma well within Thrinchostoma (Fig. 3). Many genera and subgenera of parasitic halictine bees make their host genus or subgenus paraphyletic. Examples include Lasioglossum (Paralictus) [parasite] and Lasioglossum (Dialictus) [host], Echthralictus and Homalictus, Megalopta (Noctoraptor) and Megalopta (Megalopta), Megommation (Cleptommation) and other pollen-collecting subgenera of Megommation. In fact, Sphecodini is unusual among halictine cleptoparasites in that it represents an ancient parasitic lineage that has no close association with other non-parasitic groups of Halictinae. This may help explain its broad host usage. Our results place Parathrincostoma within a group of species in the subgenera Eothrinchostoma and Diagonozus, neither of which occurs in Madagascar. Michener (1978a, p. 313) com- mented on the morphological similarity between Parathrincostoma and Eothrinchostoma and speculated that Parathrincostoma may have arisen within mainland Africa and subsequently gone extinct, leaving the sole extant species on Madagascar. Given the placement of Parathrincostoma it would now be appropriate to treat these two species as a subgenus of Thrinchostoma (Tab. III). It is clear from our results that the subgeneric limits within Thrinchostoma need to be revised.

Finally, our results provide strong support for monophyly of Michener's (2000) Patellapis sensu lato. This group lacks clear morphological synapomorphies and some characters unite elements of Patellapis with other genera/subgenera of halictine bees (e.g., the unusual structure of the hind tibial and sternal scopa in the subgenus Pachyhalictus is reminiscent of Homalictus). The molecular data unambiguously support monophyly of this group (bootstrap support of 100 with introns included and 96 with introns excluded). However, most subgenera within Patellapis appear paraphyletic or polyphyletic. One obvious example is $P$. (Zonalictus) which appears as two unrelated lineages. The lineage including $P$. (Zonalictus) zacephalum occurs at high elevations in the eastern part of South Africa (Mpumalanga) while the lineage including $P$. (Zonalictus) albofasciatus occurs at lower elevations throughout southern and western South Africa. A broader survey of $P$. (Zonalictus) species, which occur north to the Arabian peninsula (Michener, 2000), will be needed to establish if these are indeed distinct clades. The one synapomorphy uniting $P$. (Zonalictus) is the white, yellow or pearlybanded margins of the abdominal terga. Bands such as these have arisen in unrelated bee groups (Nomiocolletes [Colletidae], Nomiinae [Halictidae], and Amegilla [Apidae]) and may prove to be convergent within Patellapis. We hope our results will provide impetus for taxonomic revisionary work at the species and subgeneric levels within Patellapis.

\section{ACKNOWLEDGEMENTS}

We are grateful to collaborators (indicated in supplementary Table published as online material) who provided specimens for this study. The 
Table III. Classification of the subfamily Halictinae. Tribal names are based on family group names listed in Michener (1986). Numbers of species are derived from Michener (2000), and other recent publications (e.g., Janjic and Packer 2003).

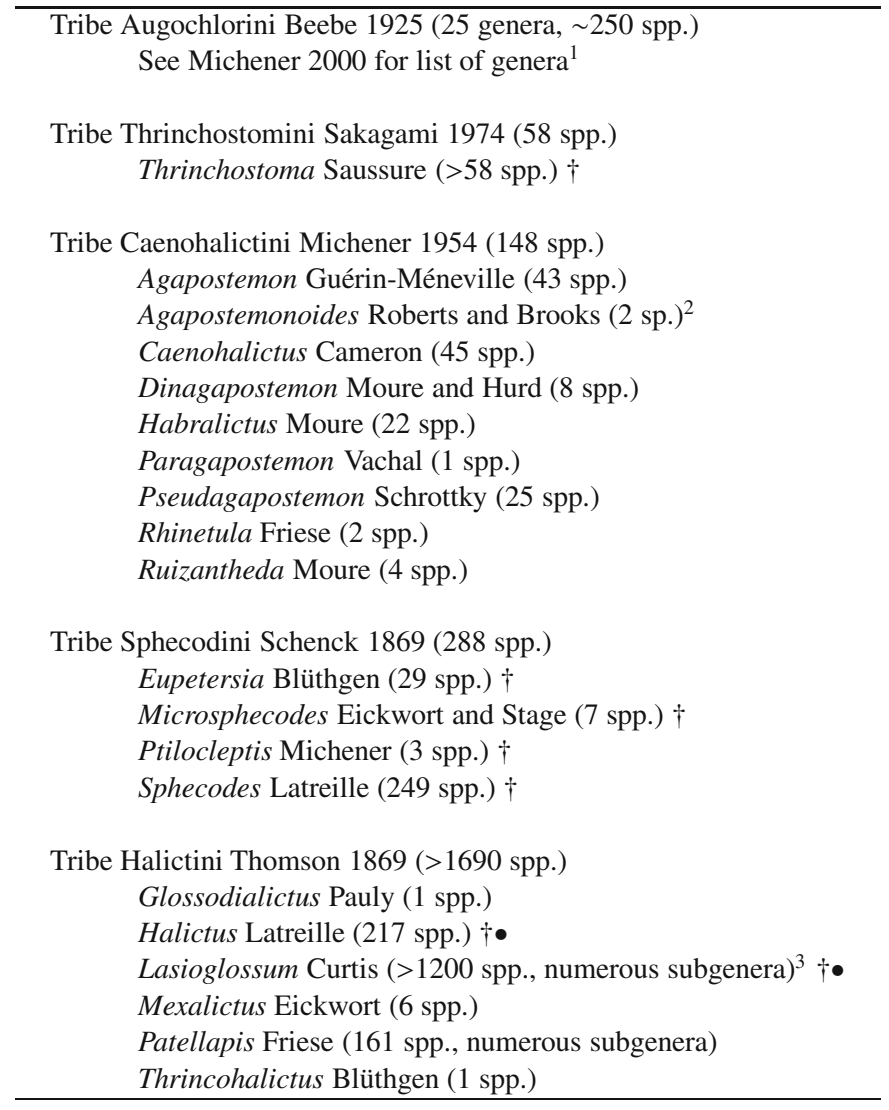

${ }^{1}$ See Eickwort (1969b) and Engel (2000) for generic treatments of the Augochlorini.

${ }^{2}$ Agapostemonoides was recognized as a subgenus of Agapostemon by Michener. Recent cladistic studies (Janjic and Packer, 2003) demonstrated that this is a valid genus.

${ }^{3}$ Lasioglossum in our sense includes Homalictus, Echthralictus, and Urohalictus.

- Indicates genera with both solitary and eusocial species; $†$ indicates taxa with cleptoparasitic species.

following people commented on early drafts of this paper: Sophie Cardinal, Jesse Litman, Sebastien Patiny, and Michael Kuhlmann. Three reviewers made significant improvements to the manuscript. Michael Kuhlmann kindly provided species-level identifications for Patellapis s.s. from South Africa. This project was supported by a National Science Foundation Research Grant in Systematic Biology (DEB-0211701) with travel funds provided by the National Geographic Society (NGS grant No. 694601 to BND, CE, LP, and KW). Permits for collecting in South Africa were obtained by Connal Eardley. Permits for collecting in Madagascar were obtained from the National Association for the Management of Protected Areas (ANGAP), the Department of Water and Forests (DEF), and the Ministry of Higher Education of Madagascar. We are grateful to the Institute for the Conservation of Tropical Environments (http://icte.bio.sunysb.edu/) for facilitating our research and travel in Madagascar.

Phylogénie des Halictidae avec une étude plus particulière sur les Halictinae africaines endémiques.

Apoidea / évolution / biogéographie / abeille / Afrique 
Zusammenfassung - Phylogenie der Halictidae unter besonderer Berücksichtigung endemischer Halictinae aus Afrika. In der Bienenfamilie Halictidae sind über 3500 Arten aus allen Kontinenten beschrieben. Diese Familie vereint die verschiedensten Bienentaxa, darunter solitäre, soziale, kleptoparasitische und sozialparasitische Arten. Viele Arten sind bezüglich ihrer Trachtpflanzen Generalisten, andere Spezialisten. Unsere Untersuchungen konzentrieren sich auf die Unterfamilie Halictinae, zu der die allermeisten Arten gehören. Wir analysierten die evolutionsbiologischen Beziehungen bei den verschiedenen Unterfamilien, Tribus und Gattungen der Halictiden unter besonderer Berücksichtigung der endemischen afrikanischen Halictinae. Verglichen mit Vertretern der Halictiden aus anderen Teilen der Welt hat man den afrikanischen Gattungen und Untergattungen bisher wenig Beachtung geschenkt. Wir wissen bisher sehr wenig über ihr Sozial- und Nistverhalten und wie diese Bienen in die Phylogenie der Halictiden einzuordnen sind. Wir analysierten die DNASequenzen von drei Genen (long-wavelength opsin, wingless und elongation factor- $1 \alpha$ ) und einen Datensatz von insgesamt 2536 Nukleotide unter Verwendung von Alignment-Analysen und Parsimony-Methoden. Anhand unserer Ergebnisse identifizierten wir zwei distinkte endemische afrikanische Abstammungslinien. Erstens den Tribus Thrinchostomini (einschließlich der Gattungen Thrinchostoma und Parathrincostoma), der früh im Stammbaum abzweigt. Zweitens eine gut abgesicherte monophyletische Gruppe (Patellapis sensu lato), die offensichtlich nahe verwandt mit dem Genus Mexalictus ist, der ausschließlich in hochgelegenen Gebieten vom westlichen Nordamerika bis nach Zentralamerika vorkommt. Dieses ungewöhnliche biogeographische Muster könnte darauf hinweisen, dass eine ursprünglich über die gesamte nördliche Hemisphäre verbreitete Gruppe ausgestorben ist. Wir überprüfen die Literatur $\mathrm{zu}$ den Halictiden bezüglich ihrer Beziehung zu Trachtpflanzen, ihrer Nistbiologie und dem Vorkommen von Kleptoparasitismus. Unsere Untersuchungen erlauben erstmals eine Beurteilung der Verwandtschaftsverhältnisse innerhalb der Halictinae anhand umfangreicher Proben aller afrikanischen Gattungen und Untergattungen.

Evolution / Biogeographie / Bienen / Apoidea

\section{REFERENCES}

Abrams J., Eickwort G.C. (1980) Biology of the communal sweat bee Agapostemon virescens (Hymenoptera: Halictidae) in New York State, Search: Agriculture (Cornell University Agricultural Experiment Station publication) 1980, pp. 1-19.
Arneson L., Wcislo W.T. (2003) Dominantsubordinate relationships in a facultatively social, nocturnal bee, Megalopta genalis (Hymenoptera: Halictidae), J. Kans. Entomol. Soc. (Suppl.) 76, 183-193.

Ascher J.A., Danforth B.N., Ji S. (2001) Phylogenetic utility of the major opsin in bees (Hymenoptera: Apoidea): a reassessment, Mol. Phylogenet. Evol. 19, 76-93.

Batra S.W.T. (1966a) Nests and social behavior of halictine bees of India (Hymenoptera, Halictidae), Indian J. Entomol. 28, 377-393.

Batra S.W.T. (1966b) Social behavior and nests of some nomiine bees in India (Hymenoptera, Halictidae), Insectes Soc. 13, 145-154.

Bogusch P., Kratochvíl L., Straka J. (2006) Generalist cuckoo bees (Hymenoptera: Apoidea: Sphecodes) are species-specialist at the individual level, Behav. Ecol. Sociobiol. 60, 422-429.

Bohart G.E. (1972) Management of wild bees for pollination of crops, Annu. Rev. Entomol. 17, 287312.

Brady S.G., Sipes S.D., Pearson A., Danforth B.N. (2006) Recent and simultaneous origins of eusociality in halictid bees, Proc. R. Soc. London, Ser. B (Biological Sciences) 273, 1643-1649.

Cardale J.C. (1993) Hymenoptera: Apoidea, in: W.W.K. Houston, G.V. Maynard (Eds.), Zoological Catalogue of Australia, AGPS Vol. 10, Canberra, pp. 167-235.

Coelho B.W.T. (2002) The biology of the primitively eusocial Augochloropsis iris (Schrottky, 1902) (Hymenoptera: Halictidae), Insectes Soc. 49, 181190.

Crespi B.J. (1996) Comparative analysis of the origins and losses of eusociality: causal mosaics and historical uniqueness, in: Martins E.P. (Ed.), Phylogenies and the comparative method in animal behavior, Oxford University Press, New York, pp. 253-287.

Danforth B.N. (1989) Nesting behavior of four species of Perdita (Hymenoptera: Andrenidae), J. Kans. Entomol. Soc. 62, 59-79.

Danforth B.N. (1999) Phylogeny of the bee genus Lasioglossum (Hymenoptera: Halictidae) based on mitochondrial cytochrome oxidase, Syst. Entomol. 24, 377-393.

Danforth B.N. (2002) Evolution of sociality in a primitively eusocial lineage of bees, Proc. Natl. Acad. Sci (USA) 99, 286-290.

Danforth B.N., Eickwort G.C. (1997) The evolution of social behavior in the augochlorine sweat bees (Hymenoptera: Halictidae) based on a phylogenetic analysis of the genera, in: Crespi B.J., Choe J.C. (Eds.), The Evolution of Social Behavior in Insects and Arachnids, Cambridge University Press, Cambridge, pp. 270-292.

Danforth B.N., Ji S. (2001) Australian Lasioglossum + Homalictus form a monophyletic group: resolving the "Australian enigma", Syst. Biol. 50, 268-283. 
Danforth, B.N., Sauquet H., Packer L. (1999) Phylogeny of the bee genus Halictus (Hymenoptera: Halictidae) based on parsimony and likelihood analyses of nuclear EF-1 $\alpha$ sequence data, Mol. Phylogenet. Evol. 13, 605-618.

Danforth B.N., Conway L., Ji S. (2003) Phylogeny of eusocial Lasioglossum reveals multiple losses of eusociality within a primitively eusocial clade of bees (Hymenoptera: Halictidae), Syst. Biol. 52, 23-36.

Danforth B.N., Brady S.G., Sipes S.D., Pearson A. (2004) Single copy nuclear genes recover Cretaceous age divergences in bees, Syst. Biol. 53, 309-326.

Danforth B.N., Sipes S.D., Fang J., Brady S.G. (2006) The history of early bee diversification based on give genes plus morphology, Proc. Natl. Acad. Sci. (USA) 103, 15118-15123.

Eickwort G.C. (1969a) Tribal positions of western Hemisphere green sweat bees, with comments on their nest architecture (Hymenoptera: Halictidae), Ann. Entomol. Soc. Am. 62, 652-660.

Eickwort G.C. (1969b) A comparative morphological study and generic revision of the augochlorine bees (Hymenoptera: Halictidae), Univ. Kans. Sci. Bull. 48, 325-52.

Eickwort G.C. (1978) Mexalictus, a new genus of sweat bees from North America, J. Kans. Entomol. Soc. 51, 567-580.

Eickwort G.C. (1986) First steps into eusociality: the sweat bee Dialictus lineatulus, Fla. Entomol. 69, 742-754.

Eickwort G.C., Eickwort J.M, Gordon J., Eickwort M.A. (1996) Solitary behavior in a high-altitude population of the social sweat bee Halictus rubicundus (Hymenoptera: Halictidae), Behav. Ecol. Sociobiol. 38, 227-233.

Engel M.S. (1995) Neocorynura electra, a new fossil bee species from Dominican amber (Hymenoptera: Halictidae), J. N.Y. Entomol. Soc. 103, 317-323.

Engel M.S. (1996) New augochlorine bees (Hymenoptera: Halictidae) in Dominican amber, with a brief review of fossil Halictidae, J. Kans. Entomol. Soc. 69 (Suppl.), 334-345.

Engel M.S. (2000) Classification of the bee tribe Augochlorini (Hymenoptera: Halictidae), Bull. Am. Mus. Nat. Hist. 250, 1-89.

Engel M.S. (2001) A monograph on the Baltic amber bees and evolution of the Apoidea (Hymenoptera), Bull. Am. Mus. Nat. Hist. 259, 1-192.

Engel M.S. (2005) Family-group names for bees (Hymenoptera: Apoideae), Am. Mus. Novit. 3476, $1-33$.

Engel M.S., Archibald S.B. (2003) An early Eocene bee (Hymenoptera: Halictidae) from Quilchena, British Columbia, Can. Entomol. 135, 63-69.

Engel M.S., Rightmyer M.G. (2000) A new augochlorine bee in Tertiary amber from the Dominican
Republic (Hymenoptera: Halictidae), Apidologie 31, 431-436.

Faith D.P. (1992) Conservation evaluation and phylogenetic diversity, Biol. Conserv. 61, 1-10.

Felsenstein J. (1985) Confidence limits on phylogenies: an approach using the bootstrap, Evolution 39, 783-791.

Grixti J.C., Packer L. (2006) Changes in the bee fauna (Hymenoptera: Apoidea) of an old field site in southern Ontario, revisited after 34 years, Can. Entomol. 138, 147-164.

Immelman K., Eardley C.D. (2000) Gathering of grass pollen by solitary bees (Halictidae: Lipotriches) in South Africa. Mitt. Mus. Nat. kd. Berl., Zool. Reihe 76, 263-268.

Janjic J., Packer L. (2003) Phylogeny of the bee genus Agapostemon (Hymenoptera: Halictidae), Syst. Entomol. 28, 101-123.

Knerer G. (1973) Periodizität und Strategie der Schmarotzer einer sozialen Schmalbiene Evylaeus malachurus (K.), Zool. Anz. 190, 41-63.

Knerer G., Schwarz M. (1976) Halictine social evolution: the Australian enigma, Science 194, 445448.

Knerer G., Schwarz M. (1978) Beobachtungen an australischen Furchenbienen (Hymenoptera; Halictinae), Zool. Anz. 200, 321-333.

Kukuk P.F. (1992) Social interactions and familiarity in a communal halictine bee Lasioglossum hemichalceum, Ethology 91, 291-300.

Kukuk P.F., Crozier R.H. (1990) Trophallaxis in a communal halictine bee Lasioglossum (Chilalictus) erythrurum, Proc. Natl. Acad. Sci. (USA) 87, 5401-5404.

Kukuk P.F., Sage G.K. (1994) Reproductivity and relatedness in a communal halictine bee, Lasioglossum (Chilalictus) hemichalceum, Insectes Soc. 41, 443-455.

Kukuk P.F., Schwarz M. (1987) Intranest behavior of the communal sweat bee Lasioglossum (Chilalictus) erythrurum (Hymenoptera: Halictidae), J. Kans. Entomol. Soc. 60, 5864.

Kukuk P.F., Schwarz M. (1988) Macrocephalic male bees as functional reproductives and probable guards, Pan-Pac. Entomol. 64, 131-137.

Legewie H. (1925) Zum Problem des tierischen Parasitismus I. Teil: Die Lebensweise der Schmarotzerbiene Sphecodes monilicornis K. (= subquadratus SM.), (Hym.: Apidae), Z. Morphol. Ökol. Tiere 4, 430-464.

MacKay P.A., Knerer G. (1979) Seasonal occurrence and abundance in a community of wild bees from an old field habitat in southern Ontario, Can. Entomol. 111, 367-376.

McConnell-Garner J., Kukuk P.F. (1997) Behavioral interactions of two solitary, halictine bees with comparisons among solitary, communal and eusocial species, Ethology 103, 19-32. 
Michener C.D. (1974) The Social Behavior of the Bees, Belknap Press, Cambridge.

Michener C.D. (1978a) The parasitic groups of the Halictidae (Hymenoptera: Apoidea), Univ. Kans. Sci. Bull. 51, 291-339.

Michener C.D. (1978b) The classification of halictine bees: tribes and old world nonparasitic genera with strong venation, Univ. Kans. Sci. Bull. 51, 501538.

Michener C.D. (1986) Family-group names among bees, J. Kans. Entomol. Soc. 59, 219-234.

Michener C.D. (1990) Reproduction and castes in social halictine bees, in: W. Engels (Ed.), Social Insects: an Evolutionary Approach to Castes and Reproduction, Springer, New York, pp. 77-121.

Michener C.D. (2000) The Bees of the World, Johns Hopkins University Press, Baltimore, MD.

Michener C.D., Poinar Jr. G. (1996) The known bee fauna of the Dominican amber, J. Kans. Entomol. Soc. 69 (Suppl.), 353-361.

Minckley R.L., Wcislo W.T., Yanega D., Buchmann S.L. (1994) Behavior and phenology of a specialist bee (Dieunomia) and sunflower (Helianthus) pollen availability, Ecology 74, 1406-1419.

Moure J.C., Hurd Jr. P.D. (1987) An Annotated Catalog of the Halictid Bees of the Western Hemisphere (Hymenoptera: Halictidae), Smithsonian Institution Press, Washington, DC.

Nel A., Petrulevièius J.F. (2003) New Paleogene bees from Europe and Asia, Alcheringa 27, 277-293.

Packer L. (1993a) Multiple foundress associations in sweat bees (Hymenoptera: Halictidae), in: L. Keller (Ed.), Queen Number and Sociality in Insects, Oxford University Press, Oxford, pp. 214233.

Packer L. (1993b) Two distinctive new species of halictine bees from high altitude in the New World tropics (Hymenoptera: Halictidae), Can. J. Zool. 71, 1653-1662.

Packer L. (1997) The relevance of phylogenetic systematics to biology: examples from medicine and behavioral ecology, Mém. Mus. Natl. Hist. Nat. 173, 11-29.

Packer L. (2006) Use of artificial arenas to predict social organization in halictine bees: data for fourteen species from Chile, Insectes Soc. 53, 307315.

Packer L., Taylor J.S. (1997) How many hidden species are there? An application of the phylogenetic species concept to genetic data for some comparatively well known bee "species", Can. Entomol. 129, 587-594.

Packer L., Jessome V., Lockerbie C., Sampson B. (1989) The phenology and social biology of four sweat bees in a marginal environment: Cape Breton Island, Can. J. Zool. 67, 2871-2877.

Patiny S., Michez D., Danforth B.N. (2007) Phylogenetic relationships and host-plant evo- lution within the basal clade of Halictidae (Hymenoptera, Apoidea), Cladistics, DOI: 10.1111/j.1096-0031.2007.00182x.

Pauly A. (1990) Classification of the African Nomiinae (Hymenoptera Apoidea Halictidae), Mus. R. Afr. Cent. Tervuren Belgique 261, 1-206.

Pauly A. (1999) Classification des Halictini de la Région Afrotropicale (Hymenoptera Apoidea Halictidae), Bull. Inst. R. Sci. Nat. Belg., Entomol. 69, 137-196.

Pauly A. (2007) Nouvelles espèces remarquables de Pachyhalictus Cockerell, avec un catalogue des espèces du genre (Hymenoptera: Halictidae), Notes Fauniques Gembloux 60, 3-12.

Pauly A., Brooks R.W., Nilsson L.A., Pesenko Y.A., Eardley C.D., Terzo M., Griswold T., Schwarz M., Patiny S., Munzinger J., Barbier Y. (2001) Hymenoptera Apoidea de Madagascar et des Iles Voisines, Mus. R. Afr. Cent. Tervuren Belgique 286, 1-390.

Pesenko Y.A. (1999) Phylogeny and classification of the family Halictidae revised (Hymenoptera: Apoidea), J. Kans. Entomol. Soc. 72, 104-123.

Pesenko Y.A. (2000) Phylogeny and classification of bees of the tribe Nomioidini (Hymenoptera, Halictidae), Entomol. Obozr. 79, 210-226 [in Russian].

Pesenko Y.A., Pauly A. (2005) Monograph of the bees of the subfamily Nomioidinae (Hymenoptera: Halictidae) of Africa (excluding Madagascar), Ann. Soc. Entomol. Fr. (n.s.) 41, 129-236.

Radchenko V.G. (1979) The nesting of Nomioides minutissimus (Rossi) (Hymenoptera, Halictidae), Entomol. Obozr. 58, 762-765 [in Russian] (English translation in Entomol. Rev. 58, 71-74).

Ribble, D.W. (1965) A revision of the banded subgenera of Nomia in America, Univ. Kans. Sci. Bull. 45, 277-357.

Richards M.H. (2000) Evidence for geographic variation in colony social organization of an obligately social sweat bee, Lasioglossum malachurum Kirby (Hymenoptera; Halictidae), Can. J. Zool. 78, 1259-1266.

Roberts R.B., Brooks R.W. (1987) Agapostemonine bees of Mesoamerica. (Hymenoptera: Halictidae), Univ. Kans. Sci. Bull. 53, 357-392.

Rozen J.G. Jr. (2000) Systematic and geographical distributions of neotropical cleptoparastic bees, with notes on their modes of parasitism. Anais do IV Encontro sobre Abelhas, Ribeirão Preto - SP, Brazil, pp. 204-210.

Sakagami S.F. (1991) The halictine bees of Sri Lanka and the vicinity. II. Nesohalictus (Hymenoptera Halictidae), Zool. Sci. 8, 169-178.

Sakagami S.F., Munakata M. (1972) Distribution and bionomics of a transpalearctic eusocial halictine bee, Lasioglossum (Evylaeus) calceatum, in northern Japan, with reference to its solitary life cycle at high altitude, J. Fac. Sci. Hokkaido Univ. Ser. 6 (Zool.) 18, 411-439. 
Sakagami S.F., Kato M., Ichino T. (1991) Thrinchostoma (Diagonozus) asianum sp. nov.: Discovery of an African subgenus of long-malared halictine bees from Sumatra, with some observations on its oligotrophy to Impatiens, Tropics 1, 49-58.

Schwarz M.P., Richards M.H., Danforth B.N. (2006) Changing paradigms in insect social evolution: insights from halictine and allodapine bees, Annu. Rev. Entomol. 52, 127-150.

Seger J. (1991) Cooperation and conflict in social insects, in: J.R. Krebs, N.B. Davies (Eds.), Behavioural Ecology: An Evolutionary Approach, 3rd ed., Blackwell Scientific, London, pp. 338373.

Sick M., Ayasse M., Tengö J., Engels W., Lübke G., Francke W. (1994) Host-parasite relationships in six species of Sphecodes bees and their halictid hosts: Nest intrusion, intranidal behavior, and Dufour's gland volatiles, J. Insect Behav. 7, 101117.

Smith A.R., Wcislo W.T., O'Donnell S. (2003) Assured fitness returns favor sociality in a mass provisioning sweat bee, Megalopta genalis (Hymenoptera: Halictidae), Behav. Ecol. Sociobiol. 54, 14-21.

Soucy S.L. (2002) Nesting biology and socially polymorphic behavior of the sweat bee Halictus rubicundus (Hymenoptera: Halictidae), Ann. Entomol. Soc. Am. 95, 57-65.

Soucy S.L., Danforth B.N. (2002) Phylogeography of the socially polymorphic sweat bee Halictus rubicundus (Hymenoptera: Halictidae), Evolution 56, 330-341.

Swofford D.L. (2002) PAUP*. Phylogenetic Analysis Using Parsimony (* and other methods), Version 4 [4.0b 10], Sinauer Associates, Sunderland, MA.

Tchuenguem Fohouo F.-N., Messi J., Pauly A. (2002) L'activité de butinage des Apoïdes sauvage (Hymenoptera Apoidea) sur les fleurs de maïs à Yaoundé (Cameroun) et réflexions sur la pollinisation des graminées tropicales, Biotechnol. Agron. Soc. Environ. 6, 87-98.

Tchuenguem Fohouo F.-N., Pauly A., Messi J., Brückner D., Ngamo Tinkeu L., Basga E. (2004) Une abeille afrotropicale spécialisée dans la récolte du pollen de Graminées (Poaceae): Lipotriches notabilis (Schletterer 1891) (Hymenoptera Apoidea Halictidae), Ann. Soc. Entomol. Fr. (n.s.) 40, 131-143.

Timmermann K., Kuhlmann M. (2008) The biology of a Patellapis (s. str.) species (Hymenoptera: Apoidea: Halictidae): sociality described for the first time in this bee genus, Apidologie 39, 189197.

Vogel M.E., Kukuk P.F. (1994) Individual foraging effort in the facultatively social halictid bee, Nomia (Austronomia) australica (Smith), J. Kans. Entomol. Soc. 67, 225-235.
Walker K.L. (1986) Revision of the Australian species of the genus Homalictus Cockerell (Hymenoptera: Halictidae), Mem. Mus. Victoria 47, 105-200.

Walker K.L. (1993) Pachyhalictus stirlingi (Cockerell) (Hymenoptera: Halictidae): A unique Australian bee, Aust. Entomol. 20, 59-65.

Walker K.L. (1995) Revision of the Australian native bee subgenus Lasioglossum (Chilalictus) (Hymenoptera, Halictidae), Mem. Mus. Victoria $55,1-423$.

Walker K.L. (1996) A new species of Australian Pachyhalictus Cockerell (Hymenoptera: Halictidae), Aust. Entomol. 23, 125-131.

Walker K.L. (1997) Supplement to a revision of Australian members of the bee genus Homalictus (Cockerell) (Hymenoptera: Halictidae), Mem. Mus. Victoria 56, 69-82.

Walker K.L. (2006) Australian Faunal Directory. Hymenoptera Apoidea Electronic catalogue http// www.environment.gov.au. Australian Biological Resources Study, Australian Government, Department of the Environment, Water, Heritage and the Arts, Accessed 14 February 2007.

Wcislo W.T. (1993) Communal nesting in a North American pearly-banded bee, Nomia tetrazonata, with notes on nesting behavior of Dieunomia heteropoda, Ann. Entomol. Soc. Am. 86, 813-821.

Wcislo W.T., Buchmann S.L. (1995) Mating behaviour in the bees, Dieunomia heteropoda and Nomia tetrazonata, with a review of courtship in Nomiinae, J. Nat. Hist. 29, 1015-1027.

Wcislo W.T., Engel M.E. (1997) Social behavior and nest architecture of nomiine bees, J. Kans. Entomol. Soc. 69 (1996 Suppl.), 158-167.

Wcislo W.T., Danforth B.N. (1997) Secondarily solitary: the evolutionary loss of social behavior, Trends Ecol. Evol. 12, 468-474.

Wcislo W.T., Minckley R.L., Spangler H.C. (1992) Pre-copulatory courtship behavior in a solitary bee, Nomia triangulifera Vachal (Hymenoptera: Halictidae), Apidologie 23, 431-442.

Wcislo W.T., Wille A., Orozco E. (1993) Nesting biology of tropical solitary and social sweat bees, Lasioglossum (Dialictus) figueresi Wcislo and Lasioglossum (D.) aeneiventre (Friese) (Hymenoptera: Halictidae), Insectes Soc. 40, 21-40.

Wcislo W.T., Arneson L., Roubik D.W., Roesch K., Gonzalez V.H., Smith A.R., Fernandez H. (2004) The evolution of nocturnal behavior in sweat bees, Megalopta genalis and M. ecuadoria (Hymenoptera: Halictidae): an escape from competitors and enemies? Biol. J. Linn. Soc. 83, 377387.

Wheeler W.M. (1928) The Social Insects: Their Origin and Evolution, Kegan Paul, Trench, Trubner and Co., Ltd. London, xviii+378 pp.

Yanega D. (1988) Social plasicity and early-diapausing females in a primitively social bee, Proc. Natl. Acad. Sci. (USA) 85, 4374-4377. 